\title{
Correlates of Knowledge about Sexually Transmitted Diseases (STDs) among Youths in Nepal
}

\section{Vikash Kumar KC, Shiva Bahadur Karki \& Bipin raj Niraula}

\begin{abstract}
Cross sectional and nationally representative sample drawn from Nepal Adolescent and Youth Survey 2011, this paper attempts to examine the correlates associated with knowledge about sexually transmitted diseases (STDs) among young population in Nepal. Univariate, bivariate and multivariate analyses have been used to examine the correlates associated with the knowledge about sexually transmitted diseases among youths. Bivariate analysis reveals that education, mass media exposure, mother's education, marital status, ecological belts and regions are significantly associated $(p<0.001)$. However, multivariate analysis shows that education and mass media exposure are the strong factors $(p<0.001)$ associated with knowledge of at least one STD among youths after controlling others variables in the model. A special attention should be given to girls' education particularly for the rural, remote and interior parts of the country. In addition, IEC through mass media may be an immediate action to improve the level of knowledge and awareness about STDs among youths in Nepal.
\end{abstract}

Key words: correlates, knowledge, Nepal, sexually transmitted diseases, youths

\section{Introduction}

Sexually transmitted diseases (STDs) (also known as sexually transmitted infections) are the diseases, which are transferred from one person to another through sexual contacts. STDs not only transmit through intercourse, but also through kissing, oralgenital contact and use of sex toys. In the beginning of twentieth century, least attention was paid about the incidence of STDs (Gonorrhea and Syphilis) although an incidence was common in Europe, Africa, and Asia and Pacific regions, however, the study on STDs geared up especially after the emergence of HIV/AIDS during 1980 (Cates, 2001). This is because of the reason that the chance of acquiring HIV infection is manifold (between two to five times) higher among the persons living with any STDs (WHO, 2008). Annually it is estimated 448 millions of infections occur worldwide in adult aged 15-49 years and this does not include HIV and other STDs which severely affect the lives of people and communities (Workowski, 2010 \& Hopwood, 2001).

Youth is the transitional stage of life cycle in which various changes such as, physiological, physical, psychological and social occur (Brown, Sadler, Tomkins, McGarrigle, LaMontagne, Goldberg, et al. 2004). Youths are more susceptible to STDs than adults because of poor knowledge about the outcomes of risky behavior, peer pressure and their biological vulnerability. The recent trend reveals that almost half of 
the new cases of STDs occur among youths annually and the infection is one of the leading causes of morbidity and mortality at the global level. (Weinstock, Berman, Cates, 2004; Fageeh, 2008; Stone, Ingham, Simkhada, 2003). These evidences reveal that youths are at the center of acquiring STDs. A study made by Wasserheit (1992) has claimed that individuals who are infected with STDs are at least two to five times more likely than uninfected individuals to acquire HIV infection if they are exposed to the virus through sexual contacts. Knowledge is the first step of protecting people from the diseases and an adequate and proper knowledge about STDs may be an appropriate preventive measure. Several studies at the global level show that age, sex, ethnicity, place of residence and parental education are significantly related to the knowledge of STDs among youths (Stone, Ingham \& Simkhada, 2003, MOPH; New ERA and IFC International, 2012; Upreti, Regmi, Pant \& Simkhada, 2009; Samkange-Zeeb, Spallek $\&$ Zeeb, 2011). Although a large number of cross sectional KAP studies on STDs including HIV/AIDS has been conducted in the context of Nepal by taking sample for the specific areas, none of the studies are based on the nationally representative sample. Thus this study may be new one in terms of its coverage. This paper aims to examine the correlates associated with knowledge of STDs among young population of Nepal.

\section{Data and Methods}

Nepal is a predominantly agricultural country in which about 70.0 percent of total population (76.0 percent of household) rely on agriculture for their livelihood (CBS, 2011a). Topographically, the country is divided into three distinct belts: Mountain, Hill and Tarai and is further divided in five development regions (Eastern, Central, Western, mid Western and far Western), 14 zones and 75 districts administratively. The latest population census 2011 records 26.42 million population comprising 48.5 percent male and 51.5 percent female. More than 16.0 percent of the total population is between the age of 15 and 24 years. The census also records 83.0 percent (as compared with 17.0 percent urban) rural population. This figure is based on the government classification of 58 municipalities as urban areas and 3913 village development committees (VDCs) as rural (CBS, 2011b).

This paper uses the cross sectional data drawn from a nationally representative sample of Nepal Adolescent and Youth Survey (NAYS) 2010/11 conducted by Ministry of Population and Health (MOPH) Nepal. The study was initiated in early 2010 and the data collection was carried out between September and December 2010. The main purpose of the survey was to generate specific data for formulating the policies and programs on various issues of adolescent and youth. For sampling design, this survey uses two stages stratified sampling techniques in which 300 EAs (enumeration areas or clusters) were selected using probability proportion to size comprising rural and urban samples (237 rural and remaining 63 urban clusters) at the first stage. In the second stage, 30 households from each clusters were selected using systematic random sampling. Finally, a total of 8155 adolescent and youth (3663 boys and 4492 girls) aged 15-24 year from 9000 households were chosen.

The survey had administered household and individual questionnaires. Household questionnaire collected information on basic household and individual characteristics 
Janapriya Journal of Interdisciplinary Studies, Vol. 2, No.1 (December 2013)

and individual questionnaire collected information on various issues (attitudes, perception and practices towards marriage, fertility, health behavior, sexuality and etc.) associated with adolescent and youth. The individual questionnaires were administered to all young people of age 10-24 years through direct interviewed by the trained interviewer.

Data analyses have been performed in three stages. First, univariate analysis (percentages) has been used. Secondly, bivariate (Chi square test for independence) and finally multivariate analyses (binary logistic regression) have been used to explore the joint effect of explanatory variables on knowledge and perception about STDs. The binary logistic regression model has been used as a multivariate technique due to dichotomous (yes or no) nature of response variable. Those associations having p-values less or equal to 5.0 percent are regarded as statistically significant. SPSS version 16.0 has been used to analyze the data.

\section{Measurement of variables}

\section{Dependent variable}

The main response variable for the present study is the knowledge of at least one STD. To measure this variable, the respondents were asked whether they heard about any type of STDs. The outcome of this variables is dichotomous: yes or no.

\section{Explanatory variable}

The main explanatory variables are age, education, sex, marital status, mass media exposure, household economic status, parental (father's and mother's) education, development regions, ecological belts and place of residence. Although the country comprises five development regions, this study assumes Kathmandu valley as an additional development region. Therefore, the analysis is based on six development regions. The rationale of selecting these variables as explanatory is explained previously.

\section{Results}

Table 1 shows the percent of youths classified according to selected background characteristics. About six in ten respondents are under the age of 20 years. In terms of educational status, 45.0 percent followed by 41.6 percent and 13.3 percent have acquired secondary, SLC and above and primary level education respectively. Majority of respondents are girls (55.1 percent against 44.9 percent) and unmarried (71.8 percent). More than 13.0 percent of youths have low exposure to mass media. About 40.0 percent of youths are from the household with poor economic condition. An overwhelming proportion of parents (77.0 percent mothers and 42.0 percent fathers) are illiterate. About one in every two youths are from hill region as compared with 44.0 percent from Tarai and 8.3 percent from Mountain. 
Janapriya Journal of Interdisciplinary Studies, Vol. 2, No.1 (December 2013)

Table 1: Percent of respondents classified according to selected background characteristics, Nepal, 2011

\begin{tabular}{|c|c|c|c|}
\hline Characteristic & $\begin{array}{l}\text { Percent } \\
\mathrm{n}(\%)\end{array}$ & Characteristic & $\begin{array}{l}\text { Percent } \\
\mathrm{n}(\%)\end{array}$ \\
\hline Age & & Primary & $642(9.3)$ \\
\hline $15-19$ & $4882(59.9)$ & Secondary & $629(9.1)$ \\
\hline $20-24$ & $3273(40.1)$ & SLC and above & $320(4.6)$ \\
\hline Education $\dagger$ & & Father's education \# & \\
\hline Primary & $964(13.3)$ & Illiterate & $2879(42.0)$ \\
\hline Secondary & $3274(45.1)$ & Primary & $1306(19.0)$ \\
\hline SLC and above & $3014(41.6)$ & Secondary & $1594(23.2)$ \\
\hline Sex & & SLC and above & $1077(15.7)$ \\
\hline Boy & $3663(44.9)$ & Regions & \\
\hline Girl & $4490(55.1)$ & Eastern & $1802(22.1)$ \\
\hline Marital status & & Central & $2019(24.8)$ \\
\hline Never married & $5853(71.8)$ & Western & $1656(20.3)$ \\
\hline Married & $2302(28.2)$ & Mid-western & $1000(12.2)$ \\
\hline Mass media exposure* & & Far-western & $795(9.7)$ \\
\hline Low & $1032(13.4)$ & Kathmandu & $883(10.8)$ \\
\hline Moderate & $4798(62.2)$ & Ecological belts & \\
\hline High & $1885(24.4)$ & Mountain & $673(8.3)$ \\
\hline HH economic condition & & Hill & $3892(47.7)$ \\
\hline Poor & $3232(39.6)$ & Tarai & $3590(44.0)$ \\
\hline Medium & $3400(41.7)$ & Place of residence & \\
\hline Rich & $1532(18.7)$ & Rural & $6497(79.7)$ \\
\hline Mother's education! & & Urban & $1658(20.3)$ \\
\hline Illiterate & $5324(77.0)$ & $\mathrm{N}$ & 8155 \\
\hline \multicolumn{4}{|c|}{$\begin{array}{l}\text { † } 903 \text { cases are missing due to non response } \\
\text { * } 440 \text { cases are missing due to non response } \\
\text { \# } 1299 \text { cases are missing due to the exclusion of literate category } \\
\text { ! } 1240 \text { cases are missing due to the exclusion of literate category }\end{array}$} \\
\hline
\end{tabular}

\section{Bivariate Analysis}

For bivariate analysis, Chi Square test for independence has been used and only the associations that have $p$ values less or equal to 0.05 have been explained. Table 2 reveals that percent distribution of youths who have heard at least one STD by selected background characteristics. Education, marital status, mass media exposure, mother's education, regions, and ecological belts have a strong association with knowledge of STDs. For example, a higher proportion of youths with better education, high exposure 104 
Janapriya Journal of Interdisciplinary Studies, Vol. 2, No.1 (December 2013)

to mass media know about any STDs. Youths whose mothers acquire SLC and above are more likely to know about any STDs as compared with illiterate mothers. Among the development regions, a higher percent of youths from Kathmandu and eastern development region know about any STDs than youths from other regions.

Table 2: Percent of respondents who have heard of at least one STD (Gonorrhea, Syphilis, HIV/AIDS and Others) by selected characteristics, Nepal, 2011

\begin{tabular}{|c|c|c|c|}
\hline Characteristic & $\begin{array}{l}\text { Percent } \\
\mathrm{n}(\%)\end{array}$ & Characteristic & $\begin{array}{l}\text { Percent } \\
\mathrm{n}(\%)\end{array}$ \\
\hline Age & & Primary & $521(81.9)$ \\
\hline $15-19$ & $3737(77.2)$ & Secondary & $542(86.3)$ \\
\hline $20-24$ & $2501(76.9)$ & SLC and above & $274(86.4)$ \\
\hline Education $* * *$ & & Father's education ${ }^{\star *}$ & \\
\hline Primary & $689(71.8)$ & Illiterate & $1985(69.5)$ \\
\hline Secondary & $2537(78.1)$ & Primary & $1030(79.6)$ \\
\hline SLC and above & $2495(83.5)$ & Secondary & $1279(80.9)$ \\
\hline Sex & & SLC and above & $898(83.9)$ \\
\hline Boy & $2802(77.1)$ & Regions ${ }^{\star * *}$ & \\
\hline Girl & $3434(77.0)$ & Eastern & $1457(81.0)$ \\
\hline Marital status ${ }^{\star \star *}$ & & Central & $1441(72.0)$ \\
\hline Never married & $4593(79.0)$ & Western & $1318(80.3)$ \\
\hline Married & $1645(72.0)$ & Mid-western & $648(65.0)$ \\
\hline Mass media exposure ${ }^{\star * \star}$ & & Far-western & $599(77.4)$ \\
\hline Low & $682(66.3)$ & Kathmandu & $775(87.8)$ \\
\hline Moderate & $3669(77.1)$ & Ecological belts ${ }^{* * *}$ & \\
\hline High & $1587(84.5)$ & Mountain & $479(72.8)$ \\
\hline HH economic condition & & Hill & $3101(80.0)$ \\
\hline Poor & $2491(77.6)$ & Tarai & $2658(74.7)$ \\
\hline Medium & $2592(76.9)$ & Place of residence & \\
\hline Rich & $1155(76.3)$ & Rural & $4965(77.0)$ \\
\hline Mother's education $^{\star \star \star}$ & & Urban & $1273(77.4)$ \\
\hline Illiterate & $3889(73.6)$ & $\mathrm{N}$ & 6238 \\
\hline \multicolumn{4}{|c|}{$\begin{array}{l}{ }^{*} \mathrm{p}<0.05,{ }^{* *} \mathrm{p}<0.01 \text { and }{ }^{* * *} \mathrm{p}<0.001 \text { (based on Chi Square test) } \\
\text { Notes: Data in table excludes missing responses } \\
\text { Although Chi Square test uses both responses (yes or no), the table only provides } \\
\text { positive response (yes). }\end{array}$} \\
\hline
\end{tabular}

\section{Multivariate Analysis}

Table 3 shows the odds ratio from logistic regression model of knowledge of STDs 
Janapriya Journal of Interdisciplinary Studies, Vol. 2, No.1 (December 2013)

among youths by selected background characteristics. Table 3 includes three models: model 1, model 2 and model 3 . In model 1, only the demographic factors have been included for binary logistic analysis. The analysis reveals that education, sex, and marital status of young people are strongly related to knowledge of at least one STD. For example, education is positively related to knowledge of at least one STD (the odds of knowing about is more than 5.0 times (CI, 4.98, 5.76) among youths having SLC and above education as compared with youths acquiring primary education). Married youths are more likely to know about STD than their unmarried counterparts.

Model 2 comprises two factors: demographic and household factors in which education, sex, marital status, mass media exposure are significantly associated with knowledge of STDs. Youths having SLC and above education are 2.8 (CI, 2.61, 3.45) times more likely to know about STDs than youths having primary level education after controlling remaining variables in the model. Girls are less likely to know (odds ratio 0.81 (CI, $0.70,0.93$ ) for girls) about any STDs than boys. Mass media exposure also appears as a strong predictor of knowledge of STDs among youths. The odds of knowing STDs is 4.56 (CI, 4.19, 5.21) times among youths having high exposure to media as compared to low exposure after controlling the remaining variables in the model.

Model 3 contains all the explanatory variables (demographic, household and spatial). Education, mass media exposure, and regions (central and mid western) are strongly related with knowledge of STDs among youths after controlling other variables in the model and these factors have more of less similar association as in model 2.

Table3: Adjusted odds ratio from logistic regression models of knowledge of at least one STD (Gonorrhea, Syphilis, HIV/AIDS and Others) among youths by selected background characteristics, Nepal, 2011

\begin{tabular}{|c|c|c|c|c|c|c|}
\hline \multirow[t]{2}{*}{ Characteristic } & \multicolumn{2}{|c|}{ Model 1} & \multicolumn{2}{|c|}{ Model 2} & \multicolumn{2}{|c|}{ Model 3} \\
\hline & Coef. & $\begin{array}{l}\text { Adjusted Odds } \\
\text { Ratio } \\
(95.0 \% \mathrm{CI})\end{array}$ & Coeff. & $\begin{array}{l}\text { Odds ratio } \\
(95.0 \% \mathrm{CI})\end{array}$ & Coef. & $\begin{array}{l}\text { Adjusted Odds } \\
\text { Ratio } \\
(95.0 \% \mathrm{CI})\end{array}$ \\
\hline \multicolumn{7}{|l|}{$\begin{array}{l}\text { Demographic } \\
\text { factor }\end{array}$} \\
\hline \multicolumn{7}{|l|}{ Age } \\
\hline $15-19(\mathrm{r})$ & & 1 & & 1 & & 1 \\
\hline $20-24$ & -0.18 & $0.83(0.72,0.96)$ & -0.19 & $0.82(0.71,0.98)$ & -0.15 & $0.86(0.73,1.02)$ \\
\hline \multicolumn{7}{|l|}{ Education } \\
\hline Primary $(r)$ & & 1 & & 1 & & 1 \\
\hline Secondary & 0.32 & $\begin{array}{l}1.72(1.61, \\
2.13)^{* * *}\end{array}$ & 0.10 & $1.92(1.74,2.10)^{\star \star}$ & 0.12 & $\begin{array}{l}1.89(1.72, \\
2.98)^{\star * *}\end{array}$ \\
\hline SLC and above & 0.44 & $\begin{array}{l}5.24(4.98, \\
5.76)^{* * *}\end{array}$ & 0.25 & $2.81(2.61,3.45)^{\star \star * \star}$ & 0.22 & $\begin{array}{l}2.80(2.63, \\
3.11)^{\star * * *}\end{array}$ \\
\hline \multicolumn{7}{|l|}{ Sex } \\
\hline Boy $(r)$ & & 1 & & 1 & & 1 \\
\hline Girl & -0.21 & $\begin{array}{l}0.81(0.73, \\
0.91)^{\star * *}\end{array}$ & -0.21 & $0.81(0.70,0.93)^{* * *}$ & \begin{tabular}{|l|}
-0.18 \\
\end{tabular} & $0.83(0.73,0.97)^{\star}$ \\
\hline Marital status & & & & & & \\
\hline
\end{tabular}


Janapriya Journal of Interdisciplinary Studies, Vol. 2, No.1 (December 2013)

\begin{tabular}{|c|c|c|c|c|c|c|}
\hline Never married (r) & & 1 & & 1 & & 1 \\
\hline Married & 0.27 & $\begin{array}{l}1.31(1.12 \\
1.54)^{* * *}\end{array}$ & 0.27 & $1.45(1.28,1.88)^{\star * *}$ & 0.20 & $1.22(1.02,1.08)^{\star * *}$ \\
\hline \multicolumn{7}{|l|}{ Household factor } \\
\hline \multicolumn{7}{|l|}{ MME } \\
\hline Low (r) & & & & 1 & & 1 \\
\hline Moderate & & & 0.46 & $2.56(2.41,2.84)^{\star * *}$ & 0.47 & $\begin{array}{l}2.63(2.51 \\
2.71)^{* * *}\end{array}$ \\
\hline High & & & 0.68 & $4.56(4.19,5.21)^{\star * *}$ & 0.70 & $3.50(3.39,3.65)^{\star * *}$ \\
\hline \multicolumn{7}{|l|}{$\mathrm{HH}$ eco. condition } \\
\hline Poor $(r)$ & & & & 1 & & 1 \\
\hline Medium & & & 0.03 & $1.03(0.97,1.20)$ & 0.06 & $1.06(0.91,1.24)$ \\
\hline Rich & & & 0.14 & $1.42(1.25,1.89)$ & 0.14 & $1.15(0.92,1.44)$ \\
\hline \multicolumn{7}{|l|}{$\begin{array}{l}\text { Mother's educa- } \\
\text { tion }\end{array}$} \\
\hline Illiterate $(\mathrm{r})$ & & & & 1 & & 1 \\
\hline Primary & & & -0.11 & $0.89(0.70,1.18)$ & \begin{tabular}{|l|}
-0.07 \\
\end{tabular} & $0.93(0.73,1.19)$ \\
\hline Secondary & & & -0.43 & $0.65(0.49,0.86)^{\star *}$ & \begin{tabular}{|l|}
-0.36 \\
\end{tabular} & $0.70(0.53,0.94)$ \\
\hline SLC and above & & & -0.48 & $0.68(0.43,1.12)^{\star}$ & -0.26 & $0.77(0.53,1.14)$ \\
\hline \multicolumn{7}{|l|}{ Father's education } \\
\hline Illiterate $(\mathrm{r})$ & & & & 1 & & 1 \\
\hline Primary & & & -0.25 & $0.78(0.65,0.95)$ & -0.25 & $0.77(0.64,0.94)$ \\
\hline Secondary & & & -0.16 & $0.86(0.71,1.13)$ & -0.13 & $0.87(0.71,1.07)$ \\
\hline SLC and above & & & -0.18 & $0.85(0.70,1.12)$ & \begin{tabular}{|l|}
-0.18 \\
\end{tabular} & $0.84(0.64,1.09)$ \\
\hline \multicolumn{7}{|l|}{ Spatial factor } \\
\hline \multicolumn{7}{|l|}{ Regions } \\
\hline Eastern $(\mathrm{r})$ & & & & & & 1 \\
\hline Central & & & & & 0.56 & $\begin{array}{l}1.73(1.40 \\
2.13)^{\star * *} \\
\end{array}$ \\
\hline Western & & & & & 0.23 & $1.25(0.99,1.58)$ \\
\hline Mid-western & & & & & 0.89 & $\begin{array}{l}2.45(1.94 \\
3.09)^{* * *}\end{array}$ \\
\hline \begin{tabular}{|l|} 
Far-western \\
\end{tabular} & & & & & 0.15 & $1.17(0.88 .1 .56)$ \\
\hline Kathmandu & & & & & 0.02 & $1.01(0.72,1.39)$ \\
\hline \multicolumn{7}{|l|}{ Ecological belts } \\
\hline Mountain (r) & & & & & & 1 \\
\hline Hill & & & & & -0.17 & $0.85(0.65,1.11)$ \\
\hline Tarai & & & & & 0.03 & $1.03(0.79(1.39)$ \\
\hline \multicolumn{7}{|l|}{ Place of residence } \\
\hline Rural (r) & & & & & & 1 \\
\hline Urban & & & & & \begin{tabular}{|l|}
-0.09 \\
\end{tabular} & $0.91(0.74,1.11)$ \\
\hline Constant & -0.86 & $0.43^{\star * *}$ & -0.41 & $0.66^{* * *}$ & -0.73 & $0.48^{\star \star \star}$ \\
\hline Chi Square & & $28.61^{\star *}$ & & $24.13^{\star *}$ & & $21.43^{\star *}$ \\
\hline
\end{tabular}

\section{Discussion}

In bivariate analysis without controlling the influence of other variables, education, 
Janapriya Journal of Interdisciplinary Studies, Vol. 2, No.1 (December 2013)

mass media exposure, marital status, mother's education, regions and ecological belts appear as significant factors. However, in the final model of multivariate analysis after controlling the effect of other variables, education and mass media exposure are strong factors associated with knowledge of at least one STD among youths. As expected, education is one of the important factors that enables adolescents and youths to know more about any STDs and their preventive measures. The finding of this study is also supported by a large number of studies at the global level (Sekirime, Tamale, Lule \& Wabwire-Mangen, 2001; Svenson, Varnhagen, Godin \& Salmon, 1992; Tyden, 1991; Fageeh, 2008).

This study also shows that mass media exposure is also a strong positive predictor of knowledge of STDs among youths. It is obvious that mass media (especially radio, TV and newspaper) facilitates to learn more about diseases. Various studies at global level also confirm this finding ( $\mathrm{Li}, \mathrm{Wu}, \mathrm{Lin}, \mathrm{Guan}$, Rotheram-Borus \&Lu, 2009; Gruber \& Grube, 2009).

There is a significant regional variation in knowledge of STDs indicating that youths in central development region are more likely to know about any STDs than the youths from eastern development region after controlling remaining variables in the model. This result is as anticipated because of the reason that youths from central development region are more empowered in terms of mass media and other intervention programs related to HIV/AIDS awareness. Although youths in mid western development region are less empowered in terms of education and intervention programs related to mass media, the odds of STDs knowledge is higher than eastern development region. Therefore, further research may be the better option for drawing a firm conclusion.

\section{Conclusion}

The finding of this study is conclusive that educational attainment and mass media exposure are the strong factors associated with the knowledge of STDs among youths in Nepal. First, a priority is to be given for youths' education (particularly for the girls from interior, rural and remote parts of the country). Education not only provides knowledge about STDs but also teaches several dimensions of living health life among young population. Secondly, mass media (especially FM radio and TV) are one of the important sources of generating awareness toward the diseases and their prevention. Therefore, information, education and communication through radio and TV may an immediate actions for improving current level of knowledge among youths and general population as well.

\section{References}

Brown, A.E., Sadler, K.E., Tomkins, S.E., McGarrigle, C.A., LaMontagne, D.S., Goldberg, D. et al. (2004). Recent Trends in HIV and Other STIs in the United Kingdom: Data to the end of 2002. Sexually Transmitted Infections, 80:159-66.

Cates, W.J. (2001). Treating STDs to help control HIV infection. Contemporary Obs/ Gyn, 46 (10): 107-115.

CBS (2011a). Nepal Living Standards Survey 2010/11: Statistical Report volume II. CBS (2011b). Population census of Nepal, 2011: preliminary report. Central Bureau 
Janapriya Journal of Interdisciplinary Studies, Vol. 2, No.1 (December 2013)

of Statistics.

Fageeh, W.M. (2008). Awareness of sexually transmitted diseases among adolescents in Saudi Arabia. Journal of King Abdulaziz University, 15 (1): 77-90.

Gruber, E. \& Grube, J.W. (2000). Adolescent sexuality and media: a review of current knowledge and implications. Culture and Medicine, 172: 210-214.

Hopwood, N.J. (2001) The onset of human puberty: biological and environmental factors. In Bancroft J, Reinisch JM, Eds. Adolescents and Puberty. New York, Oxford University Press, 29-49.

KC, Vikash (2007). Knowledge, incidence and treatment seeking behavior of sexually transmitted diseases (STDs) in the context of HIV/AIDS among Nepalese men. Paper presented in 17th biennial meeting of ISSTDR, Washington, July 29 to August1, 2007.

Li, L., Wu, Z., Lin, C., Guan, J., Rotheram-Borus, M. J., \& Lu, Y. (2009). Mass media and HIV/AIDS in China. Journal of Health Communication, 14 (5): 424-438.

Ministry of Health and Population (MOPH) [Nepal], New ERA \& IFC international Inc. (2012). Nepal Demographic and Health Survey 2011.

Samkange-Zeeb, F., Spallek, L. \& Zeeb, H. (2011). Awareness and knowledge of sexually transmitted diseases (STDs) among school going adolescents in Europe: a systematic review of published literature. BMC Public Health, 11: 727

Sekirime, W.K., Tamale, J., Lule, J.C. \&Wabwire-Mangen, F. (2001). Knowledge, attitude and practice about sexually transmitted diseases among university students in Kampala. African Health Science, 1 (1): 16-23.

Stone, N., Ingham, R, \& Simkhada, P. (2003). Knowledge of sexual health issues among unmarried young people in Nepal. Asia Pacific Population Journal, 18 (2): 33-54.

Svenson, L. W., Varnhagen, C.K., Godin, C. K. \& Salmon, T.L. (1992). Rural high school students KAP related to STDs. Canadian Journal of Public Health, 83 (4): 260-63.

Tyden, T. (1991). Sex, Contraception and STDs among female university students in Sweden. Advertisement of Contraception, 7 (2-3): 165-71.

Uprety, D., Regmi, P., Pant, P. \& Simkhada, P. (2009). Young people's knowledge, attitude, and behavior on STI/HIV/AIDS in the context of Nepal: A systematic review. Kathmandu University Medical Journal, 7 (4): 383-391.

United Nations. (2006). United Nations Programs on AIDS Report on the global AIDS.

Wasserheit, J.N. (1992). Epidemiological synergy. Interrelationship between human immunodeficiency virus and other sexually transmitted diseases. Journal of Sexually Transmitted Diseases, 19 (2): 61-77.

Weinstock, H., Berman, S., Cates, W. (2004). Sexually transmitted diseases among American youth: incidence and prevalence estimates, 2000. Perspectives on Sexual and Reproductive Health, 36(1):6-10

Workowski, K.A. \& Berman, S. (2010). Sexually transmitted diseases treatment guidelines. MMWR 2010 Recomm Rep. 2010 Dec 17;59(RR-12):1-110.

World Health Organization (2008). Global Incidence and Prevalence of selected curable sexually transmitted infections. World health Organization. 2008. 